\title{
Research Paper An economic analysis due to municipal solid waste in Coimbatore district of Tamil Nadu
}

\section{R. Sunandhini and C. Sekar}

ABSTRACT : Negative externalities caused by municipal solid waste have led to severe pollution of

See end of the paper for authors' affiliations

Correspondence to :

\section{R. Sunandhini}

Department of Agricultural

Economics, Centre for

Agriculture and Rural

Development, Tamil Nadu

Agricultural University,

Coimbatore (T.N.) India

Email: sunandhinir@gmail.

com

\section{Paper History :}

Received : 21.06.2020;

Revised : 07.07 .2020

Accepted : 08.08 .2020 surface and groundwater sources and health status, which have ultimately affected the livelihood of the poor. Environmental problems in the agricultural sector and household sector caused by solid waste in Coimbatore district have been discussed in this study. Garrett's Score and Contingent Valuation technique have been employed for this purpose. The major constraints faced by the respondents were health hazards, unpleasant odour, poor land quality and poor quality of irrigation water. The farmers and the households in the study area are well aware about the detrimental effects of solid waste and they have expressed their willingness to pay for internalizing the negative externalities even though it is duty of local institution/Government.

KEY WORDS : Municipal solid waste, Garrett's score, Contingent valuation technique

How To Cite This PAper : Sunandhini, R. and Sekar, C. (2020). An economic analysis due to municipal solid waste in Coimbatore district of Tamil Nadu. Internat. Res. J. Agric. Eco. \& Stat., 11 (2) : 144-149, DOI : 10.15740/HAS/IRJAES/11.2/144-149. Copyright@2020:Hind Agri-Horticultural Society. 